\title{
MILLENARIAN PROPHECY AND THE MYTHIFICATION OF PHILIP III AT THE TIME OF THE EXPULSION OF THE MORISCOS
}

\author{
Grace Magnier \\ Trinity College Dublin
}

In their task of justifying retrospectively the expulsion of the Moriscos, the Catholic apologists all resort to a mythification of Philip III. In doing this they rely on the mediaeval political prophecies commonly in circulation in the Iberian peninsula. All ap ologists tend to use similar sources. The primary ones are the works of Joachim of Fiore and his followers, whose millenarian biblical exegesis was grafted onto the mediaeval millenarian Siby lline prophecies, the fourth-century Tiburtina and the seventh-century Pseudo-Methodius, from which the my th of the Emp eror of the Last Days evolved. In the Spanish version of this my th the reconquest of North Africa precedes that of Jerusalem. All the ap ologists indulge in rhetorical admonitions to Philip III to follow up his conquest of Islam in Spain, which is how they view his expulsion of the Moriscos, by imitating the mythical journey of the Last World Emperor and proceeding towards Jerusalem via North Africa. The king's sons are admonished to mount symbolically the Holy Hill of Sion. ${ }^{1}$

Relying on both the indigenous prophetic tradition, falsely ascribed to St. Isidore or Merlin, and the Mediaeval Eritraean Sibyl, all the apologists equate with Philip III the lion

1. “El segundo es, ver las felicidades que publican de V. altezas doctos y graues Pronosticos, fundados en los selestiales Astros, prometiẽdoles la conquista y triumpho de Ierusalem, y libertad del santo Sepulchro, cõ notables victorias de los Mahometanos, dando por tierra sus menguantes Lunas y poniendo en su lugar la Cruz santissima, començandose esto despues de la Expulsion de los Moriscos de España”: M. DE Guadalajara Y JaVIER, “Dedicatoria a los serenissimos principes de España”, Memor a ble expvlsion y ivstissimo destierro de los moriscos de España, II (P amplona: Nicolás de AssiAYN, 1613), fols A5-A5v. Richard Kagan has pointed out that “fulfilment prophecies” were customary on the birth of a royal prince. This served the purpose of confirming for the people the divine approval of the monarchy. He points out that López Cañete reproduces those that accompanied the births of the sons of Philip IV, Princes Charles and Ferdinand: R. KAgAn, Lucrecia's Dreams: Politics and Prophecy in Sixteenth-Century Spain (Berkeley: University of California Press, 1990), p. 3. I have, in the text of this talk, referred to that of Blessed Nicholas Factor given at the birth ofFerdinand, son of Philip III. 
which is destined to conquer Asia and overcome the beast of Islam. The divine election of Spain for this task was revealed by the Great Conjunction of 1603 which confirmed this special role for Sagittarian Spain. The nativity horoscope of Philip III confirmed this also. ${ }^{2}$

Finally the apologists cite spurious biblical figurae to attempt to show that Spain had been singled out for this special role from biblical times. Pedro Aznar Cardona comp ares Philip III with the angel of Revelation who turned the rivers and streams to blood as a sign of God's vengeance. All apologists refer to extraordinary phenomena that indicate divine concern at the continuing presence of the Moriscos in Spain. Those described by Damián Fonseca are apocalyptic in character.

\section{MILLENARIAN POLITICAL PROPHECIES}

I shall first look at the political prophecies or pronósticos so very popular in spite of the ban of Pope Sixtus V. ${ }^{3}$ Used by the Catholic apologists of the expulsion they cast Philip III in a mythical, warlike role. All have strong millenarian and apocaly ptic overtones. Many consider that the king, now that the Moriscos have been expelled, has been singled out by God to continue his anti-Islamic crusade by proceeding by way of North Africa to the Holy Land where he will reconquer Jerusalem:

Despues de destruyda la secta mahometana en España y echados los moros, se tratara en ella de la recuperacion de la Tierra Santa de Hierusalem, y se pregonara guerra

Belief of the pre-eminence of Spain among Christian nations is evident in the picture of the great lion of Spain brandishing a sword of virtue that has been reserved for him alone. I shall return to this image later and link it with the Great Lion of Judah of the Book of Revelation. The bloody imposition of baptism by force is ironic given the great controversy raised by the mass expulsion of Moriscos, all of whom had been baptised:

[...] Este exercito passara por el estrecho de Gibraltar en Africa. Y caminara a sitiar la ciudad de Lybia, o Fez. Y en ella el gran Leon de España, desembaynara una espada de virtud, que esta reseruada para el. Y proseguira su jornada por

2. The great conjunction took place in the tenth house which was also the case for the nativity horoscope of Philip III: “[...] dice Albumazar (De magnis coniunctionibus) que quando la conjuncion magna sucediere en la dezena casa de alguno, significa que llegara a posseer grande reyno”: NAVARRo, Discvrso, p. 18.

3. In his bull Caeli et terrae (1585) Pope Sixtus V banned judicial astrology: J. CARo BARoJa, Vidas mágicas e inquisición, I (Madrid: Taurus, 1967), p. 180. Juan de Horozco y Covarrubias published a copy of the bull in his Tratado de la verdadera y falsa profecia (Segovia: Juan de la Cuesta, 1588). 
Berberia, ${ }^{4}$ matando y abrassando a los que no pediran el sagrado baptismo, ni professaran el nombre de Christo. $^{5}$

The king, having marched victoriously through North Africa, is seen as conquering, with divine aid, a superior army at Alexandria and then proceeding to Jerusalem:

[el turco] se retirara a tierra adentro. Y dejandole campo franco al Rey Leon, continuara sus victorias hasta Hierusalem, y en llegando a ella se arrojara pecho por tierra, y dara gracias a Dios por tantas victorias, gracias y mercedes. ${ }^{6}$

This victorious march to liberate Jerusalem recalls that of the Emperor of the Last Days of the mediaeval Christian Sibylline prophecies. ${ }^{7}$ However, the initial march across North Africa is a specifically Spanish addition. ${ }^{8}$ This mythical figure was seen as the saviour of Christendom

4. Following the conquest of Granada and the expulsion of the Jews Isabel la católica and Cardinal Francisco Jiménez de Cisneros cherished the hope of a crusade against the infidel in North Africa. Nothing had been done by Isabel's death in 1504. Cisneros later went on two campaigns; one in 1505 when Mers-el Kebir was captured, and another in 1509 when Oran was taken: J. H. ELLIOTT, Imperial Spain (London: Arnold, 1963), pp. 41-42.

5. The Emperor Constans of the Tiburtina Sibylline prophecy also puts to the sword those heathens who refuse baptism, and in the anonymous German early sixteenth-century Book of a Hundred Chapters (MS in Colmar) a "resurrected" Frederick II would put to the sword those infidels who refused the sacrament, thus baptising themin blood: N. Cohn, The Pursuit of the Millenium (London: Mercury Books, 1957), pp. 16,121 .

6. Guadalajara Y Javier, Memorable expulsion, fols. $160^{\mathrm{v}}-161^{\mathrm{r}}$. This prophecy is ascribed to Blessed Nicholas Factor (1520-1583) although the date given by Guadajalara y Javier is 1430.

7. This figure is first mentioned in the Tiburtina Sibylline prophecy that dates from the fourth century AD. That of Pseudo-Methodius develops the character even more fully. This was composed tow ards the end of the seventh century, at the time when Christians were witnessing the rise of Islam, and was very influential during the Middle Ages. In it the sons of Ishmael are represented as cruel oppressors. These are finally defeated by a great Christian Emperor, whom men had thought to be dead, but who rose from his slumbers to defeat Islam: CoHn, The Millenium, pp. 31-32. The Pseudo-Methodius falsely purported to be the work of St. Methodius of Olympus: St. Methodius was Bishop of Lycia (d. c. 311) and was probably martyred at Chalcis in Greece: Oxford Dictionary of the Christian Church, ed. F. J. Cross \& E. A. LivingSTSONE, 2nd. ed. (London: Oxford University Press, 1974), p. 910.

8. A. Milhou, Colón y su mentalidad mesiánica en el ambiente franciscanista español (Valladolid: Casa-Museo de Colón y Seminario Americanista de la Universidad, 1983), p. 304. James II of Aragon planned such a crusade to reconquer Jerusalem. He would first reconquer Granada and then proceed to Palestine via North Africa. His personal physician and valido, Arnald of Villanova (1240-1311) was entrusted with the organisation of this crusade between the years 1306-1309. The expedition, however, 
and universal monarch, a mediaeval role which was also much cherished by Philip III's grandfather, the Emp eror Charles V. ${ }^{9}$ In fact, Charles, as grandson of the Holy Roman Emperor, Maximilian, and of Mary of Burgundy, united in his person the prophetic tradition ascribed to both the Austrian eagle and the French lily. ${ }^{10}$ During his candidacy for the Holy Roman Empire,his charismaatic name - Charles -had prompted the circulation of the "Second Charlemagne Text”. This text, originally written for Charles VI of France, saw in the bearer of this magic name the persona of the Last World Emperor. ${ }^{11}$ At the time of his election other prophecies were cited to argue that "[...] the salvation of Europe hungup on it and he who could sustain this office must be of heroic mould and vast strength”. The sack of Rome in 1527 for many "[...] fulfilled so dramatically the role of the King-Chastiser who destroys Rome that was difficult not to see it in this context”. ${ }^{12}$

In the Sibylline prophecy called the Pseudo-Methodius, greatly developed during the early expansion of Islam, the Emperor of the Last Days ushers in a Golden Age of material prosperity and peace. He will be a great Emperor, whom men have long thought dead, but who will awaken from his slumbers to wage war against the infidel. He will defeat the Ishmaelites and then journey to Jerusalem. Confronted by the Antichrist he will place his crown on the cross at Golgotha and die. The Antichrist will then go on to reign until he himself is defeated by Christ. ${ }^{13}$

Since the Middle Ages anti-Islamic polemic often described Muhammad as aprefiguration of Antichrist. ${ }^{14}$ He was represented as the vomiting dragon who thus regurgitated

never took place: MiLHou, Colón y su mentalidad mesiánica, p. 374.

9. The royal chronicler of Charles V, Juan Ginés de Sepúlveda, in his Exhortación (1527) cast the emperor in a similar role. He urged the monarch to turn from the conflict in Italy and to take up arms against the Turks who were then threatening Vienna. In so doing he would be fulfilling his divinely ordained destiny and taking a step towards a universal Christian empire. Once Greece and its neighbours had been vanquished he might conquer Asia Minor, Mesopotamia and then finally worship in the Holy City of Jerusalem: A. LosADA, Tratados políticos de Juan Ginés de Sepúlveda (Madrid: Instituto de Estudios Políticos, 1963), pp. 25-27.

10. M. REEVES, The Influence of Prophecy in the Later Middle Ages: A Study in Joachimism (Oxford: Oxford University Press, 1969), pp. 359-372.

11. The prophecy of Pseudo-Methodius, source of this myth, had begun to recirculate after the fall of Constantinople in 1453: REEVES, The Influence of Prophecy.

12. REEVES, The Influence of Prophecy, p. 362.

13. M. REEVES, “Joachimist Influences on the Idea of a Last World Emperor”, Traditio, XVII (1961), p. 324.

14. N. DANIEL, Islam and the West: The Making of an Image, 2nd ed. (Oxford: One World Publications, 1993), pp. 210-211, 218. Basing his case on a passage from the second letter of St. John (2 Jn 7), the Catholic apologist, Pedro Aznar Cardona, goes to some length to argue that Muhammad is a prefiguration of the 
the ancient heresies which he had been fed by the Devil. The Spanish polemical antialcoranes, much used as a source by the apologists, put forward this notion. ${ }^{15}$ As the ap ologists also tended to regard the expulsion as the final event in the Christian Reconquest of Spain (conveniently forgetting that the Moriscos were baptised Christians), the notion of anti-Islamic crusade is uppermost in their minds. Indeed the frontispiece of one of the ap ologetic works depicts the Hydra being slain by the Spanish Hercules. The author explains that Hercules represents Philip III and the Hydra the dragon of the Apocalypse ${ }^{16}$ whose seven heads are taken to represent the great heresies. The last and most pernicious was that of Muhammad which has been duly removed by the expulsion of the Moriscos. ${ }^{17}$

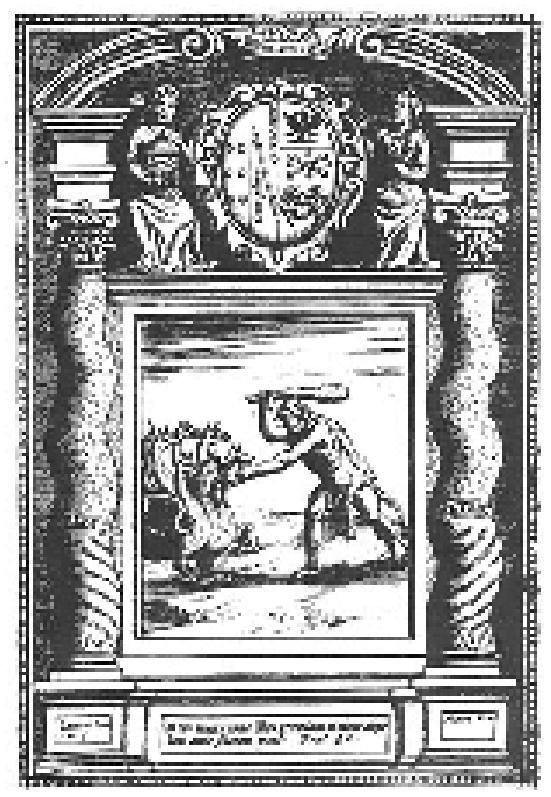

Antichrist “[...] la prophecia de San Juan, ya tantas vezes alegada, habla literalmente del sacrilego Mahoma”: P. AzNAR CARDONA, Expvlsion ivstificada de los moriscos españoles y suma de las excelencias christianas de nuestro rey D. Phelipe, tercero de este nombre, I (Huesca: Pedro Cabarte, 1612), fol. 21v

15. DANIEL, Islam and the West.

16. Apoc 11, 3-4; 13, 1-10.

17. “la septima [heresiarcha] y mas perniciosa de todas (que por eso lo deje por ultimo), es el mal profeta Mahoma, que generalmente blasphema de toda la religion christiana”: D. FonsECA, Ivsta expvlsion de los moriscos de España (Rome: Iacomo Mascardo, 1612), fol. $3^{\mathrm{v}}$. 


\section{THE RECOVERY OF JERUSALEM}

As Alain Milhou has pointed out, the recovery of Jerusalem had been a constant element in the mediaeval political prophecies since the time of Joachim of Fiore (c.1145-1202). ${ }^{18}$ This twelfth-century biblical exegete and mystic saw the world as evolving towards an immediate spiritual apotheosis, a third status or millenarian age of the Holy Spirit. Later tradition would see the defeat and conversion of the infidel and the death of the Antichrist as taking place immediately before the beginning of this third age. Then in this time of spiritual regeneration the “Eternal Evangel” of the Book of Revelation $(14,6)$ would be established.

In Spain these themes can be traced back to the Aragonese polymath Arnald of Villanova. Appointed private physician to Peter III of Aragon in 1281, in the following year he witnessed the latter's invasion of Sicily and the massacre and eventual defeat of the French which began on Easter Monday 1282, at Vespers, and is commonly called the Sicilian Vespers.

The eschatological ideas present in Villanova's commentary on the prophecy of Joachim of Fiore Vae mundo in centum annis which Villanova included in his work De cymbalis ecclesiae (1297-1301), reinforced the messianic ideals of the House of Aragon. In it he uses the title of New David, probably applied to the king of Aragon, who is given the eschatological role of reconstructing the citadel of Mount Sion in Jerusalem. ${ }^{19}$ Villanova was, thus, the first to suggest that from Spain would come the liberator of Jerusalem and re-builder of the citadel of Mount Sion. ${ }^{20}$

18. JoachimofFiore, whose work was widely influential from the thirteenth century onwards, evolved a theory in which history reflected the nature of the godhead. The meaning of history was to be found in the mysterious action of the Trinity which penetrated all ages. At times this took the form of concordances between the OT and the NT and this reflected the relationship between the Father, who is represented in the OT, and the Son who is present in the NT. The third status or age would be that of the Holy Spirit and would form the apotheosis of history when the elect would enjoy great happiness in the New Jerusalem. These three status are described in his works Liber concordiae (the first status), Expositio (the second status) and the Psalterium of the spiritualis intellectus or third status: M. REEvES, Prophecy in the Later Middle Ages (Oxford: Clarendon Press, 1969), p. 5.

19. MilHou, Colón y su mentalidad mesiánica, p. 235.

20. Milhou cites the following pasage from the Veh mundum "eritque solitudo in terra, quosque Novus David arcem Syon veniat reparare”. Considering the prominence given to the king of Aragon in the rest of the text this New David may refer to him. However, it is also possible that the reference is to a reforming pope, a “pastor angelicus” in the tradition of Joachim of Fiore: MiLHou, Colón y su mentalidad mesiánica, pp. 376-377. Sixteenth- and seventeenth-century writers, convinced of Spain's pre-emi nence among Christian nations, saw parallels between the Hill of Sion, abode of Jahweh in the Old Testament, and Spain, the country of the New Elect. Milhou reproduces an illustration from a sixteenth guide-book in which “geographical exegesis” draws parallels between the topography of Toledo and Jerusalem: R. DE YEPES, Historia de la muerte y martirio del Sancto Inocente de la Guardia (Madrid:Juan Iñíguez de Lequerica, 
Since the fall of the Latin States in the thirteenth century the recovery of Jerusalem had been an inevitable backdrop to any camp aign against Moor or Turk. ${ }^{21}$ Such a proclamation enhanced the prestige of a monarch and could even aid a usurping sovereign in his quest for legitimacy. Henry II of Trastámara attemp ted to win resp ect for his claim to the throne of Castile by declaringhis intention to conquer Jerusalem. ${ }^{22}$ Jerusalem was also used in the propaganda war in Italy when Charles VIII of France invaded that country in the late fifteenth century. For his solemn entry into Naples on 22 February 1495 the French king wore the quadruple crown of France, Naples, Constantinople and Jerusalem. ${ }^{23}$ Sicily was, of course, the source of the claim to the throne of Jerusalem, a claim which was hotly disputed by the House of Anjou and the Kingdom of Aragon. The dispute had arisen at the fall of the Latin States and was definitively ended on 7 July 1510 when Ferdinand el católico was invested as king of Jerusalem by Pope Julius II. ${ }^{24}$

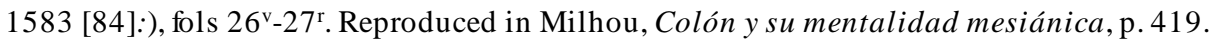

21. Mirhou, Colón y su mentalidad mesiánica, p. 400.

22. Milhou claims that the messianic prophecies were used for the first time in Castile by Henry el bastardo of Trastámara following the battle of Montiel both to enhance his prestige and to add legitimacy to his usurpation: MiLHOU, Colón y su mentalidad mesiánica, p. 357.

23. Mirhou, Colón y su mentalidad mesiánica, p. 338. The sixth-century church of Santa Sophia was converted into a mosque in the fifteenth century after the capture of Constantinople by the Turks in 1453. Its recovery for Cristianity had been the dream of Pope Calixtus III (1455-1458) who believed that God would not allow him to die until until Constantinople had been regained and the Great Turk had been personally baptised by himself in Rome. In the late fifteenth century Charles VIII of France also believed that he was destined to reconquer both Constantinope and Rome: MilHou, Colón y su mentalidad mesiánica, pp. 327-328. The recovery of Constantinope for Christianity and the rededication of the mosque was of similar symbolic value to that of the liberation of Jerusalem. Similarly, Morisco jofores would also regard the taking of Rome as symbolic of an Islamic victory. The one which claims to be that of Muhammad 'Uçmân, “ el-ke ganó a Gonstantinoble” advises his son to fodder his horse in St. Peter' s: “ I darás çebada a tu kaballo en-el-altar de Pedro i de Pablo ante ke tornes a koronarte a Gonstantinoble, i ayas s ojudgado la-faz de la-tiyerra de Levante a Poniente”: MS T18, RAH, cited in L. CARDAILLAC, Morisques et Crétiens, un affrontement polémique (Paris: Klincksieck, 1977), p. 405.

24. The disputed claim to the throne of Jerusalem reflects, in its early stages, the struggle between the papacy and the Holy Roman Emperor and later that between Ferdinand el católico and France. Charles of Anjou (1126-1185), later King of Naples, fought in the Second Crusade (1147-1149) with his brother Louis VIII (St. Louis). Following a disputed succession to the throne of Jerusalem, Pope Gregory X urged one of the claimants, Maria of Antioch, to sell her rights to Charles in opposition to Frederick II of Hohenstaufen, Holy Roman Emperor. The deed was signed in 1277: S. Runciman, History of the Crusades, III (Cambridge: Cambridge University Press, 1955), 5th. ed. (London: Penguin, 1955), pp. 330, 342. The Aragonese claim is given in an early seventeenth-century book. Fernando Matute y Acevedo claims that 
This Sibylline prophecy of Pseudo-Methodius is cited by the Catholic apologist of the expulsion of the Moriscos, Jaime Bleda, as authority for the defeat of the infidel and thebeginning of an age of peace and tranquillity:

Imponent christiani iugum super Sarracenos, et erit pax et tranquillitas magna super terram qualis non fuit antea, nec similis post illam. Porro sectam Mahometi cito finem habituram, multa praedixerunt vaticinia. ${ }^{25}$

The prestige that would accrue to the monarch following the recapture of Jerusalem and the ensuingpre-eminence of Spain is explicitly stated by another Catholicap ologist, Pedro Aznar Cardona:

La segunda cosa que debe ser hecha por nuestro prudentissimo Rey Catolico, es qu prosiga adelante en sus insignes hazañas y emprenda sin dilacion cõ su animo inuencible, la conquista de Ierusalem. Pues, a mas

Yolanda, daughter of John de Brienne, last King of Jerusalem, inherited Jerusalem from her father. She then brought it as a dowry when she married Frederick II. The latter was crowned King of Jerusalem on Easter Sunday 1229, and thus, according to Acevedo, his was the greatest claim: F. MATUTE y ACEVEDO, El triunfo del desengaño. Contra el engaño y astucia de las edades del mundo para todas las profesiones $i$ para todos estados (NAPLES: Lázaro Escorigio, 1632), p. 107. (The author was an advisor to the Viceroys of Sicily.) Frederick II had inherited Sicily from his mother Constance of Sicily: S Runciman, The Sicilian Vespers (Cambridge: Cambridge University Press, 1956), pp. 16-17, 26. Frederick's granddaughter Constance married Peter III of Aragon who thus inherited the claim to Sicily and to Jerusalem. In 1282 P et er invaded Sicily in the operation since called the Sicilian Vespers and ousted the House of Anjou. Sicily was, of course, attached to the Kingdom of Naples which later passed to the crown of Aragon following the conquest of Naples by Alfonso V between 1442 and 1443 . However, the title to Jerusalem could not be used by Aragon as this had been conferred on the House of Anjou by the papacy. The title finally passed to Aragon in 1510 by the bull of Julius II granted to Ferdinand el católico: MiLHoU, Colón y su mentalidad mesiánica, pp. 367-368. The claim to Jerusalem was a much prized one bringing with it prestige and a claim to pre-eminence. It appears very early in the titles listed for Philip III in a book published very soon after his accession to the throne. The illustration shows a very youthful Philip and the title begins thus: "Phillipus III, Rex catholicvs, defensor fidei, Hispaniarum, vtrusque Siciliae, Hierusalem, Hungriae, Dalmatia etc.”: Iconografía hispana: catálogo de los retratos de personajes españoles de la BN (Madrid: BN Sección de Estampas, 1966), 4 vols. The book from which the illustration is taken is refered to as “Una historia napolitana de fines del siglo XVI”. Lope de Vega also refers to this title in his Jerusalén conquistada: "Rey de Jerusalén, si a vuestro abuelo/ dejara Francia de ocuparle tanto,/ libre estuviera de su santo celo/ el sepulcro de Cristo, sacrosanto cielo”: L. DE VEGA, Jerusalén conquistada, ed. F. C. Sainz de Robles (Madrid: Aguilar, 1964), Book 20, p. 874.

25. J. BlEDA, Defensio fidei in cavsa neophytorum, siue Morischorum Regni Valentiae, totiusque Hispaniae [...] Et Tractatus de ivsta Morischorum ab Hispania expulsione (Valencia: Juan Chrysóstomo Garriz, 1610), p. 534. The section is subtitled “De fine saeculi”. 
de que vna empressa tan alta y de tan supremo honor, no conuiene a otro menos que a un tan alto Rey, es cierto q por muchos justos titulos le pertenece aquella tierra tã desseada de los christianos, a su Magestad y a su corona sacra. El cielo y la tierra tiene el Rey nuestro Señor en su fauor para este esclarecido y desseado hecho. [...] Esta gloriosa victoria de la Tierra Santa, felizmente començada en la saludable expulsion de los mahometanos, y reseruada por el cielo, para empleo del valor sin segundo de nuestro inclito don Felipe el catolico. ${ }^{26}$

I direct your attention to the passage that begins "una empressa tan alta y de tan supremo honor" which articulates the widely-held belief among Spaniards in the divine election of Spain. It is from this belief that Spanish presumption of pre-eminence among Christian nations derives and which underlies the phrase "El cielo y la tierra tiene el Rey nuestro Señor en su fauor para este esclarecido hecho”.

Referring once again to the conquest of Jerusalem Bleda depicts the sons of Philip III, Princes Philip and Ferdinand, symbolically mounting the Holy Hill of Sion:

Faxit Deus, vt quamcitissime haec sanctissima expeditio descernatur, tentetur \& inchoetur a domino nostro rege, qui rex Hierusalem iure vocatur, et in ea prosperum iter ad aperiat \& faciat nobis Deus salutarium nostrorum vt tandem eam benedictam terram recuperemus, Dei ope, regis Hisp aniae ingenio, Ducis Lermae suasione, vt ascendant ipse, aut alij saluatores, id est principes suae familiae in sanctum Montem Sion \& fit domino illud regnum \& alia multa.

Many prophecies make of this ascent of Mount Sion the emblematic gesture by which Islam is vanquished and Christianity restored to God's holy mountain.

Bleda rep resents the King as investing his treasure from the Indies in this war to conquer definitively the Moors and other heretics, to recover the Holy Land and to rebuild the holy church of Santa Sophia in Constantinople:

[...] omnes indicos thesauros insumere in recuperanda Terra Sancta, in debellando mauris \& hereticis, in reformando Sanctae Sophiae templo constantinopolitano.

Bleda claims that this prophecy was made by Ioannes Claromontanus in the early sixteenth century when writing about the restoration of the church of Santa Sophia in Constantiniple. ${ }^{27}$

26. Aznar Cardona, Expulsión ivstificada, II, fol $143^{\mathrm{r}}-143 \mathrm{v}$. Aznar Cardona also claims that the mysterious tolling of the church bell in Vililla (Velilla) was a portent, among other events, of the conquest of the Holy Land: AzNAR CARDONA, Expvlsion ivstificada, II, fol. $146^{\mathrm{v}}$

27. J. Claromontanus, Pronosticis de Vngarici regni factis: Bleda, Defen sio fidei, pp. 43, 436-437. Aznar Cardona claims that this pronóstico is mentioned in a book on the House of Hapsburg by a Gerónymo Gebulero (c. 1480-1545): H. GEBWEILER, Keiserlicher vnd Hispanisher $m^{t}$ auch fürstlicher Durchlüchtikeit, vnd aller hieuor, Ertzhertzogen vnd Hertzogen von Österreich, derzu der fürstlichen Grauen von Hapsburg 
Bleda and Aznar Cardona claim that these great deeds were foretold by the Great Conjunction $^{28}$ of 24 December 1603 as analysed by the “astrónomo Christiano” Dr. Francisco Navarro. This author considers that this Great Conjunction, taken with the nativity horoscop e of Philip III, shows that Spain, the new Chosen People, will liberate Jerusalem. This was foretold in the Old Testament Book of Obadiah:

Et ascendent Saluatores in montem Sion iudicare montemEsau. ${ }^{29}$

The author does not refer to the context which surely must have influenced him into making this assertion:

alt künglich Harkumen mit Namen ger nahe vff zweitusent Jar. Durch Hieronimus Gebweiller, Hiervor zu latin, vnd ietzt nachmals zu Tütsch, in diesem büchlin begriffen: (Strasbourg: J. Grienynger, 1527). Perhaps it is to be found in a book written in 1519 in support of the candidiature of Charles of Ghent for the Holy Roman Empire: H. GeBWELLE, Libertas Germaniae qua Germanos Gallis, neminem vero Gallo a christiano natali Germanis Imperasse, certissimis a classicorum scriptorum testimonijs probatur Hieronymo Gebulero authore. Cited in REEVES, “Joachimist Influences”, p. 35: AzNAR CARdONA, Expulsión ivstificada, II, fol. 149v. Dr. Francisco Navarro, an “astrónomo cristiano”, has an interesting quotation on this topic: "Gens Sagittaria regnabit tempora longa in Christicolis tuis \& reseruabitur alteri, qui erit pius, regnum Vngarorum dabitur ei et multum misericors quando Ecclesiam: ipse reformabit Ecclesiam Pragensen Sanctae Sophiae templum Constantinopolitanum scandeta ad ardua inter catholicos. Sed non de sanguine Mathiae, sed de rupibus Alemaniae orietur \& exiet rex synceris si mus [...]”: Dr. F. NAVARro, Discvurso sobre la conivncion maxima que fve en Deziembre del Año 1603. En el qual se pronostican los felicissimos sucessos, y vitorias q señala al rey don Phelipe III, nuestro señor, y a su gente sagitaria, que son los españoles (Valencia: Juan Chrysóstomo Garriz, 1604), p. 58.

28. The Themata mundi attempted to base the story of creation on such astrological premises. Great Conjunctions were also studied by those involved in writing nativities ofChrist: J. D. NORTH, Horoscopes and History (London: Warburg Institute, University of London, 1986), p. 166.

29. Abd 1, 21. An early seventeenth-century compendium of prophecies may be the source for this reference: Dr. C. LÓPEZ DE CAÑETE, Compendio de los pronosticos y baticinios antigvos y modernos que publican la declinacion de la secta de Mahoma y libertad de Hierusalem y Palestina (Granada: Francisco Heylán, 1630), fol 7v. Aznar Cardona gives an expanded version: “ Et transmigratio quae in Bosphoro est, possidebit ciuitates Austri \& ascendent Saluatores in Montẽ Syon iudicareMontẽ Esau: AznAR C ARDONA, Expulsión ivstificada, fols $150^{\mathrm{r}}-150^{\mathrm{v}}$. He explains that this prophecy of Abdias indicates that Islamwill be conquered by Spaniards who will symbolically mount the Holy Hill of Sion thence to sit in judgement on Mount Esau which he takes to represent the Moors. This exegesis is not supported by the historical facts. The Edomites, descendents of Isaac's son Esau, were despised by the Israelites because they had not come to their aid at the time of the enforced exile. The prophecy proclaims that the Israelites, the Chosen People, will return as saviours to recover the Hill of Sion and restore to it the reign of Jawé: Catholic Biblical Enclyclopedia: Old Testament, ed. J. E. Steinmueller \& K. Sullivan (New York: J. F. Wagner, 1955), pp. 4-5. 
Y los cautivos de Jerusalén, que están en Sefarad, ocuparán las ciudades del mediodía (Abd 20).

\section{THE GREAT CONJUNCTION OF 1603}

A great conjunction involves both Saturn and Jupiter. They are very infrequent, occurring every eight or nine hundred years. Some astrologers felt that such conjunctions were related to the history of great religions. That of 1603 was given such an interpretation by those at pains to justify the expulsion of the Moriscos. This is how Dr. Francisco Navarro expresses it:

Los efetos destas maximas conjunciones son mudar y alterar la vniuersal complicacion del mundo, los imperios, sectas, gouiernos, costumbres. ${ }^{30}$

According to Aznar Cardona, this extraordinary astrological configuration, that took place under the benign influence of Jupiter, denoted two things: the prosperity of Philip III and the destruction within eight years of la secta de Mahoma: ${ }^{31}$

Si credito debemos dar a la astrologia señalo para su magestad real todas estas superiores grandezas, la conjuncion maxima que fue a 24 de diciembre de 1603. Como lo dize en la figura della, bien calculada con punctual obseruacion, el doctor Francisco Nauarro, valenciano. Segun este christiano astronomo, experimentado en esta ciencia experimental, dos cosas denoto esta extraordinaria conjuncion ${ }^{32}$ con la

30. NAVARro, Discrrso, p. 7.

31. The native prophetic tradition, falsely attributed to St. Isidoro of Seville, had since the eighth century been attempting to predict the end of Islam. The earliest forecast was in the Crónica Albeldense (883 AD) written during the reign of Alfonso III of Asturias (866-910). Within this text is inserted a “crónica profética”, based on an adulterated prophecy of Ezechiel, which considered that the defeat of the Visigoths by the Arabs was God's punishment for their sins. However, within “one hundred and seventy ages” the Arabs would themselves be defeated: M. GóMEz MORENo, “Las primeras crónicas de la reconquista: el ciclo de Alfonso III”, BAH, V (1932), pp. 565, 574-576. This “Planto de España”, was falsely attributed to St Isidoro of Seville by Don Lucas of Túy (c. 1160-1249) in his Chronicon mundi and this attribution was officially confirmed in the Primera crónica general of Alfonso X: MiLHou, Colón y su mentalidad mesiánica, p. 351. A version of this prophecy was associated with the revolutionary movement of the “comuneros” and is to be found in a MS describing the period: Relaçion de todo lo sucedido en las comunides de Castilla y otros Reynos Reynando el Emperador Carlos quinto, MS 1779, BNM, fols $37^{\mathrm{v}}-38^{\mathrm{v}}$.

32. “[...] y por esto siempre que estos dos planetas se han juntado, mudandose de vna triplicidad a otra, han señalado y causado notablissimas mudanzas en las cosas susodichas, y entre todas es ta es la mas fuerte y poderosa de quantas ha auido, por ser como es en el signo de Sagitario, que es el mas fuerte signo de la triplicidad ignea, por hacerse cerca de la estrella Regia cor Scorpij, que esta a los cinco grados de Sagitario: NAVARRo, Discvurso, p. 8. 
benevola influencia de Iupiter. Vna la prosperidad reduplicada de nuestro rey don Felipe el catholico, y otra la destruycion y ruyna de la secta mahometana dentro de ocho años, contando desde el presente de 1612. [...]

This victory of Sagittarian Spaniards had been foretold by the prophets, the Sibyls and even by Christ himself in Holy Scripure:

Los santos y no santos, los christianos y los moros, los theologos y los astrologos, los prophetas extranumerales y las sibillas, y aun, a mi juycio, el mismo soberano Dios en su escriptura santa, promete a la christiandad de su magestad con sus sagitarios, ${ }^{33}$ que somos los españoles, la gloria desta tan desseada victoria de victorias, con adquisicion de todas las riquezas, prosperidades, honras, patrimonios, dignidades, reynos y prouincias poseydos de tyranos y reyes barbaros. ${ }^{34}$

As I have been saying, prophecies about the liberation of Jerusalem, followed by the recapture of the Holy Sepulchre, are a feature of many of the apologetic works. ${ }^{35}$ It was considered that Philip III had been esp ecially chosen to defend God's honour and his army was to be made up of Sagittarians, an esp ecially brave élite corps. Marcos de Guadalajara y Javier cites another prophecy, supposedly written in 1200 in Arabic and translated in 1300 by a man

33. Sagittarius is a fire sign, associated with fearless warriors and great and powerful kings. It is ruled by the planet Jupiter. There were varying opinions as to which sign of the zodiac was to be assigned to Spain as a whole. However, Ptolemy, in his Almagest, Quadripartum associated it with Sagittarius: C. Ptolemaeus, Almagestum Cl. Ptolemei, Pheludiensis Alexandrini, astronorum principis, opus ingens ac nobile omnes coeloroum motus continens (Venice: Petrus Liechtenstein, 1515), Ptolemy's Almagest, trans. \& annot. G. J. Toomer (London: Duckworth, 1984), Alfonso X, el sabio, Picatrix, Microfiche Concordances and Texts of the Royal Scriptorium: Manuscripts of Alfonso X el sabio, ed. L. Kasten \& J. Nitt (Madison: Hispanic Seminar of Mediaeval Studies, 1978), Fiche I, pp. 21-24, fiche II, p. 405, cited in M. ReILly, Alfonso $X$ as Astrologer: A Reassessment, unpublished MA thesis (Dublin: University College Dublin, 1989), pp, 17-18, 35.

34. AzNar Cardona, Expvlsion ivstificada, II, fols $144^{\mathrm{r}}-145^{\mathrm{r}}$. The Great Conjunction is also mentioned by the following apologists: G. EsCOLANO, Decada primera de la historia de la insigne y coronada ciudad yreyno de Valencia (Valencia: Pedro Patricio Mey, 1610-1611), ed. J. B. Perales (Valencia: Terraza y Aliena, 1879), II, p. 780 ; M. DE GuAdalajaRA Y JAVIER Ivstissimo destierro, II, fols $159^{\mathrm{v}}-160^{\mathrm{r}}$ Navarro in his book on the Great Conjunction predicts a return to the Golden Age: “Finalmente pronostica y señala esta conjuncion, y la vniuersal constitucion del cielo, y posicion de las planetas al tiempo della, mucha felicidad, salud, riquezas, y vniueral prosperidad por el benevolo influjo de Iupiter, y destruyda la secta Mahometica, llegaran los dorados siglos que estan cerca”: Perhaps this echoes the era of peace and prosperity that the reign of the Emperor of the last Days was to usher in: NAVARRO, Discvrso, p. 14.

35. "He querido poner estos pronosticos, por entender que se han fundado en ellos los autores, que he leydo, para dezir, que nuestro Catholico Rey, y sus serenissimos hijos, auian de quitar a los Turcos y Moros, a fuerça de armas su Imperio, y el Santo Sepulchro de Hierusalem”: GuAdAlAJARA Y JAVIER, Memorable expulsion, fol $163^{\mathrm{r}}$. 
from Mérida called Joaquín Méndez, then a slave in Jerusalem. It foretells the destruction of Islam by a king “de rostro hermoso", fair of face. ${ }^{36}$ This king will win back Jerusalem for Christianity and the aid of the infidels’ French allies will be of no avail:

Llora Agar y lamenta Nilo que no veras cumplido el milenio. Esso es el pago de tus crueldades, y el premio de tus sodomias. Hierusalem saldra de la casa de Ismael, y entrara en ella el Monte Calvario, y los estandartes de poniente. Ya me parece que siento las trompetas de los sagitarios (esto es los españoles, a quien predomina el signo de sagitario) sin que te valga, o Ismael, la ayuda de Francia: porque el Leon es muy poderoso y Saturno y Iupiter lo significan en la conjuncion.

The author interp rets this prophecy to mean that Philip III and his sons would bring to an end the Turkish Empire and win back the Holy Sepulchre. ${ }^{37}$ Dr. Francisco Navarro in his analy sis of the Great Conjunction, a source much used by the ap ologists, argues that this victory will confirm the pre-eminence and supremacy of Sagittarian Spain. He attributes this prediction to the Arab astronomer/astrologer Abu Ma'shar who lived in the eight and ninth centuries:

Coniunctio igitur Saturni et Iouis in Sagitario circa cor Scorpij per Regiam stellam de natura Iouis et Martis, ${ }^{38}$ significat $^{39}$ quod prouincia cui signum dominabitur, omnium potentissima existens eis fiet

36. Physical beauty seems to be a hallmark of conquering heroes in all prophecies, both Christian and Morisco: Cardaillac, Morisques et Crétiens, p. 413. Such is the description of the “encubierto” (described below) in the letter of Don Rodrigo Ponce de León to the Castilian nobles in 1486: “Cómo el marqués de Cádiz, don Rodrigo Ponce de León, envió a los grandes de Castilla un juycio sacado de las revelaciones y profecías de San Juan y San Isidro, que le fué enviado por un sabio”, Colección de documentos inéditos para la historia de España por el marqués de la Fuensanta del Valle (CODOIN), CVI (Madrid: Imprenta de José Perales y Martínez, 1893), p. 250. The Greek Emperor of the Tiburtina Sibylline prophecy was tall, handsome and with a radiant face: CoHN, the Millenium, p. 31. The prophecy cited above is related in full in the work of Cristóbal López de Cañete: López DE CAÑETE, Compendio, fol $23^{\mathrm{v}}$. This prophecy is one of the Byzantine and Saracen ones that circulated at the end of the twelfth and the beginning of the thirteenth centuries: P. AlPhANDÉRY, La crétienté et l'idée de croisade, II (Paris: Éditions Albin Michel, 1959), pp. 91-96

37. GuAdalajara Y JAVIER, Ivstissimo destierro, II, fols. $161^{\mathrm{v}}-163^{\mathrm{r}}$.

38. In Alfonso X's Libro de las cruzes the planet Jupiter is considered to aid the Christian Spaniards while Mars is the planet of the Arabs: Alfonso X, Libro de las cruzes, chap. LIX, fiche II, pp. 401-402, in Reilly, Alfonso X, p. 24.

39. Navarro ascribes this analysis to Abu Ma'shar: NAvARro, Discvurso, p. 30. This Arab astrologer/ astromomer, who lived during the eighth and ninth centuries of the Christian era, wrote a work on great conjunctions. This was published in Latin in the late fifteenth century: Abu Ma'shar, De magnis coniunctionibus (Augsburg: Erhardt Ratdolt, 1489). Another edition was printed in Venice in 1515. 
suprema. ${ }^{40}$

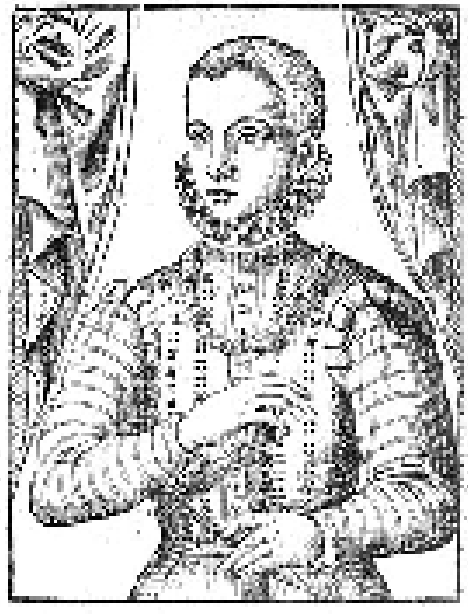

P H I L IP P S II:

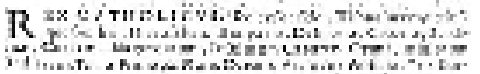

\section{“EL REY LEÓN DE ESPAÑA”:41 PHILIP III AND THE BOOK OF REVELATION}

The representation of Sp ain as a lion also has Ap ocalypticovertones and recalls the Great Lion of Judah. The lion had been of primordial importance in the Mediaeval bestiaries. There are, of course, obvious associations between the "león de España” and the heraldic emblem of the kingdom of Leon. It also formed part of the iconograp hy of the native prophetic tradition, in particular the Baladro del sabio Merlín that is found in the romance of chivalry La demanda del Santo Grial (1500).

Blas Verdú, another apologist, again specifically links this “Rey León de España” with

40. According to the Crónica profética, inserted in the Crónica Albeldense (883 AD), Arabic astrologers and astronomers were considered to have predicted the end of Islam: GómEz MorENo, Primeras crónicas”, p. 578. Aznar Cardona mentions the following: Hali (is this 'Ali ibn al-'Abbás, al-Majúsi al-Arrrajání, who wrote Liber regalis despositio nominatus ex arabico (Venice: Bernardus Ricius, 1492) and was a doctor, or Albuhali, author of De electione horarum?), Alpharabio (is this Al-Farabi a philosopher/theologian who opposed astrology?) Alchabitius ('Abd al-‘Azíz ibn Uthmán, al Habísí) whose work was printed in translation in the late fifteenth century, J. Hispalensis, Libellus ysagogicus Abdilazi... qui dicitur Alchabitus ad magisterium iudiciorum astrorum interpretatus a Joanis Hispalensis scriptum(Venice: Erhardt Ratdolt, 1485), and Albumazar (Abu Ma’shar): AzNAR CARDONA, Expvlsion ivstificada, II, fol. $144^{\text {v } . ~}$

41. The lion of the tribe of Judah is found in the following books of the Old Testament: (Gen 49, 9), (Oseas, $5,14)$ and also in $(\operatorname{Rev} 4,7,5,5)$. 
the recovery of Jerusalem. This rather nasty injunction to the king to exercise divine retribution very much embodies the spirit of the Old Testament:

Y tu nieto del Cesar Carlos Quinto [...] Ierusalem aguarda tu restauraciõ, y aquellos lugares santos donde fuyste redemido tu redempcion. Ea pues Monarcha, Leon de la casa de Austria, saca las vñas, y põ en execucion lo que manda el cielo.42

The depiction of Philip III as "el Rey León” is claimed by the apologist Jaime Bleda to be the fulfilment of a prophecy of the Eritraean Sibyl. According to this the Lion will conquer Asia, weaken it and enthrone the Lamb of the Book of Revelation (14):

Leo conteret regionem Assyae vt debilitet, \& confringat capitabestiae [sic], \& colocauit Agnumin sceptrum bestiae, ${ }^{43} \&$ usque huc sedes eius. ${ }^{44}$

42. B. VeRdú, Engaños y desengaños del tiempo con vn Discurso de la expulsion de los Moriscos de España (Barcelona: Sebastian Matheuad, 1612), fols 146v-147 . Gaspar Aguilar also expresses this notion: "Canto la eterna memorable hazaña/ de la expulsion de la Morisca gente/ por el brauo Leon que des de España/ de Africa humilla la soberuia frente": G. AGULAR, Expvlsion de los moros de España por la S. R. C. magestad del rey don Phelipe tercero, nuestro señor (Valencia: Pedro Patricio Mey, 1610), p. 1.

43. A side note in the text adds [capita bestiae] imperij orientalis.

44. BlEDA, Defensio fidei, p. 537; Guadalajara y Javier, Ivstissimo destierro, fol. 160r. This is indeed taken from the Erithraean Sibyl: O. HoLDER EGGER, “Italienische prophetien des 13. Jahrhunderts”, Neues Archiv des Gesellschaft für altere deutsche Geschichtskunde, XV (1889), p. 155. The Sibyls were considered by some of the Fathers of the Church to have foretold events in the life of Christ and Our Lady. A contemporary work on the Sibyls states: “Clemente Alexandrino [...] dize que assi como Dios, Nuestro Señor, les dio a los iudios profetas que les diessen noticia de la venida del Hijo de Dios al mundo, assi les dio a los griegos y gentiles profetisas que les diessen esta misma noticia, para que en ningun tiempo pudiessen alegar ignorancia en cosa de tanta importancia”: B. PorreÑo, Oraculos de las doçe sibilas. Profetisas de Christo, Nuestro Señor, entre los gentiles (Cuenca: Domingo de la Yglesia, 1621), fol $1^{\mathrm{r}}$. Lactantius, the Church Father, in his attempts to justify a minority religion, saw echoes of Christian teaching in the oracles of the Sibyls. He specifically refers to the Erithraean Sibyl: Lactantius, Divinae institutiones, IV, Chap. 15, 26. Eusebius, in his Life of Constantine, made the last major statement on the Sibyls. He refers to the acrostic verses found in the writings of the Erithraean Sibyl that purported to foretell the coming of Christ in the following words: "Jesus Christ Son of God, Saviour, cross". Augustine, although his familiarity with the Sibylline oracles was slight, placed them among those in the City ofGod because he considered that they had opposed false gods: Augustine, De civitate Dei, XVIII, 23. Augustine's judgement had considerable influence on the acceptance of the Sibyls as pre-Christian prophetesses: H. W. P ARKE, Sibyls and Sibylline Prophecy in Classical Antiquity, ed. B. C. McGING (London: Routledge, 1988), pp. 163-165. Both Augustine's commentary and that of Lactantius are referred to by Aznar Cardona (fol 149v). Porreño's work both reproduces the acrostic verses and says of the Eritraean Sibyl: “Pintan a ella con vn cordero, por ser este la insignia de Christo, Nuestro Señor, de quien ella dixo tantas prophecias; y así le dixo San Juan Bautista: Ecce Agnus Dei”:, Porreño, Oráculos, 71-71v. 
Acknowledging Bleda as source, Marcos de Guadalajara y Javier provides a gloss in Castilian, citing first part of the favourable horoscope of Sp ain by Cardinal Peter d'Ailly (Pedro Aliaco). May I draw your attention to the prophecy in Latin of Raymond of Verona which the author links to Spain by judicious quotation from the twelfth-century historian Petrus Comestor: ${ }^{45}$

El Cardenal Pedro Aliaco dize de [...] España: Felix faustaque est, Deo \& coelo propitio [Spain is happy and fortunate due to the favours of God and heaven]. Por lo qual vino a dezir la Sybila Eritrea: Quebratara el Leon el valor y señoria del Asia; con que quedara debilitada la gran bestia, y sobre su ceptro entroniçara el Cordero para siempre. Que el Rey de España sea este Leon: afirmalo en su pronostico del año mil quinientos sedenta y vno, Anibal Raymundo de Verona, diziendo: Illo anno Leonem robustum dentes suosostensurum, morsurumque eos qui dentes laedare conatur. ${ }^{46} \mathrm{Y}$ dize Comestor grauissimo autor en sus baticinios; Regem Hispaniae vna cum Imperatore toti Orbi dominaturum, \& Ecclesiae afflictae opem allaturum, fusis, \& profligatis vndequaque hereticis. ${ }^{47}$

This “León de España” recalls the Great Lion of Judah of the Book of Revelation who alone was found worthy to open the volume sealed with seven seals. (In the ideology of Joachim of Fiore the opening of the seventh seal heralded the beginning of the Sabbath Age.):

And one of the ancients said to me: Weep not; behold the lion of the tribe of Judah, the root ofDavid, hath prevailed to open the book and loose the seven seals thereof. ${ }^{48}$

Belief in the veracity of the Sibyls was incorporated into the Dies irae which was recited with frequency. This thirteenth-century sequence recalls the day of Judgement. In the third line the Sibyl's witness to this "day of wrath” is coupled with that of King David: “teste David cum Sibylla”. It was obligatory for the first mass on All Souls’ Day, at requiem and anniversary Masses: Oxford Dictionary of the Christian Church, ed. F. L. Cross \& F. A. Livingstone (Oxford: Oxford University Press, 1974), p. 402.

45. Guadalajara Y Javier, Ivstissimo destierro, fol 160v. Peter d'Ailly (1350-1420) believed broadly in the doctrine of great conjunctions and their value in predicting the course of Christian history. In his book $A$ Corcord of History and Astrology he argued that the stars could influence even Jesus and Mary by reinforcing their natural virtue: J. D. NORTH, Horoscopes and History (London: Warburgh Institute, University of London, 1986), pp. 164, 166.

46. Bleda, Defensio fidei, p. 537; Guadalajara y Javier, Memorable expvlsion, II, fol 160ª ; AzNAR CARDONA, Expvlsion ivstificada, II, fol $149^{\mathrm{v}}$.

47. Bleda, Defensio fidei, p. 537; Guadalajara Y Javier, Memorable expvlsion, II, fol. $160{ }^{\mathrm{r}}$. P et rus Comestor (died between 1178 and 1198), wrote the Scholasticae historiae. He was of French or Italian origin: Enciclopedia universal ilustrada (europeo-americana), XIV (Madrid: Espasa-Calpe, 1912), p. 646.

48. A p oc 5, 5. My bible is the Douai translation (1609), 3rd. impression (London: Catholic Truth Society, 1957). 
The Lion of Judah represented Christ, who was from the Chosen People, and Philip III, King of the new Elect, is here selected as the instrument of God's wrath in bringing to an end la secta de Mahoma.

Finally I quote Dr Francisco Navarro who ends his book on the Great Conjunction with a rather nasty political prophecy concerning the "León de España”. He does not give a source. This prediction depicts Islam as the embodiment of lust and sensuality, a constant jibe in anti-Islamic polemic:

Vencera el fuerte leon al libidinoso cabron. Embidioso el Gallo [France?] se atreuera al leõ. El Leon le vencera, y auido la victoria, y quitadas las mas fuertes plumas del gallo casi sin sangre boluera a sus cachorillos a los quales ternan puestos en aprieto las sierpes de Babilonia. [...] Es to me parece se puede coniecturar supuesta voluntad de Dios, a cuyas ordenes obedecen las estrellas inuiolablemente: ${ }^{49}$

\section{PHILIP III AS A PLAGUE-BEARING ANGEL OF THE APOCALYPSE}

All the apologists rely heavily on biblical figurae in their task of justifying the expulsion of the Moriscos. ${ }^{50}$ Their assumption of Spanish pre-eminence forms a background to all their assertions. Aznar Cardona uses an extract from the Pseudo-Methodius Sibylline prophecy to reinforce this belief

\section{[...] et erit regnumchristianorumexaltatum super omnia regna. ${ }^{51}$}

He claims that Philip III's divine election as defender of the Church and champion of God's honour was prefigured by the angel[s] entrusted by God to guard the gates of Paradise. Philip III has like the angel struggled tirelessly to defend the Church's dogmas and to fight on behalf of God's honour:

En fin es rey señalado por el cielo y representado en aquel relumbrante cortesano celestial, protector del

49. Navarro, Discvurso, p. 63. The depiction of the “Rey León de España” as scourge of Spanish Islamis still to be found in the reign of Philip IV: Matute y Acevedo, El triunfo del desengaño, pp. 89-90, 106.

50. The use of figurae had been practised by the prophets as eschatological symbolism in the history of salvation. Jesus also extensively alluded to figures to show how the mystery of salvation was developing in conformity with the scriptures. The Apostolic writings, particularly those of St. Paul to the Hebrews, continued this practice: Dictionary of Biblical Theology, ed. X. León-Dufour, translation directed by P. Joseph Cahill O. P. (London/Dublin: Geoffrey Chapman, 1967), pp. 152-156.

51. This line precedes a passage previously quoted: “Imponent christiani iugum super Sarracenos, et erit pax et tranquillitas magna super terram qualis non fuit antea, nec similis post illam. Porro sectam Mahometi cito finem habituram, multa praedixerunt vaticinia”, AzNAR CARDONA, Expvlsion ivstificada, II, fol. 149r. 
parayso terreno [...] En este amable angel del cielo, nos fue representado nuestro angelico Felipe, rey nuestro, saluaguarda y amparo del Parayso Espiritual de la Iglesia christiana, tutor y pacificador de la republica, protector de los opresos, conseruador de las leyes diuinas y humanas, guerreador bellicoso por las causas al honor de Dios annexas, y mantenedor de la justicia. ${ }^{52}$

He equates the King's role with that of one of the seven plague-bearing angels of Revelation who, from their vials, poured out the wrath of God up on the earth. Thus Philip III is the instrument of God's anger towards the infidel Moriscos:

Et tertius angelus effudit phialam suam super flumina et super fontes aquarum et factus est sanguis (Apoc $6,14) .^{53}$

Aznar Cardona's grounds for this assertion are rather slight: Philip III did not make the rivers run red with blood by executing the Morisco heretics even though the author felt that this would have been a reasonable punishment. ${ }^{54}$ Although the justification for this quotation is slender it is yet another example of the vengeful Old Testament God to whom all the apologists constantly refer. Aznar Cardona continues his exegesis: he claims that this passage from Revelation predicts the expulsion of the Moriscos as many had lived on the banks of the rivers Ebro, the Xalón, the Martín, the Cinca, the Segre, and also near the Marina of Valencia and “celebrated” M oncay o. He states that thepassage "et factus est sanguis" is both metap horical and literal: it refers both to the civil death and banishment of the Moriscos and to their actual physical decease. Many also expired on their voy age into exile and y et others were refused entry into their countries by right-minded people:

Hasta los montes infalibles parece les escupian de si, no consintiendoles en parte alguna, no siendoles

52. The passage continues thus: “Esle semejante [al angel], porque assí como el querubin illustrissimo con aquel estoque de dos cortes defendio, por comision de Dios, aquel Parayso illustrissimo donde estaba el arbol de la vida transitoria. Assi este nuestro rey catholiciss i mo denende con el montante de su potestad real (espada tremenda durandina, o tizona de Dios) el Parayso de la Iglesia, mas preci os o que aquel, por la presencia del arbol de la vida eterna, Christo; vedando la entrada del, a los malos espiritus, de peruersas eregias y sectas reprouadas, y desterrando los atreuidos preuaricadores de sus santas leyes” (Gen 3, 24): Aznar Cardona, Expvlsion ivstificada, II, fol. $81^{\mathrm{r}}-81^{\mathrm{v}}$. It was common in the seventeenth century for Spaniards to consider that the deeds of their country had been foretold in scripture: HERrERo GarCía, Ideas de los españoles, p. 19.

53. Apoc 16, 4. Aznar Cardona, Expvlsion ivstificada, II, fol. 90r. This also recalls the passage in Exodus in which Aaron is commanded by God to inflict the first plague upon Egypt by striking the river his rod upon the water which then turns to blood $($ Ex 7,20$)$.

54. AzNar CARDONA, Expvlsion ivstificada, II, 121v. 
de consuelo. Cumpliose aquella letra en ellos: Ipsi montes nollunt recipere fugam nostram. ${ }^{55}$

\section{POLITICAL PROPHECIES AT THE TIME OF FERDINAND EL CATÓLICO:"EL REY LEÓN”, “EL ENCUBIERTO” AND THE NEW DAVID}

All the political prophecies used by the ap ologists have previously been used in Aragon. Among those in circulation at the time of Ferdinand and Isabella the images of "rey león", "encubierto" and New David are all used. In the Baladro del sabio Merlín (1500) there are four references to Ferdinand as both "rey león" and New David. ${ }^{56}$ The epithet "encubierto", which Milhou considers to be a Hispanic version of the myth of the sleeping Emperor of the Last Days, ${ }^{57}$ is used in the letter of Rodrigo Ponce de León to the Castilian nobles (1486). ${ }^{58}$ The motive for the letter was to rouse the nobles to action in the war against Granada. It did this by ascribing to Ferdinand the eschatological qualities present in the millenarian European political prophecies. These had been adopted by the house of Aragon followingthe acquisition of Sicily in $1282 .{ }^{59}$

Related to the notion of "rey encubierto" is that of "San Fernando redivivo" by which Ferdinand el católico was considered to be in some way an embodiment of his illustrious predecessor, Ferdinand III who, at his death in 1252, was popularly acclaimed a saint. ${ }^{60}$ The Catholic ap ologist, Marcos de Guadalajara y Javier, applies this prophecy, by which someone by this name would be instrumental in the destruction of Spanish Islam, to Ferdinand, son of Philip III. On the occasion of the birth of Prince Ferdinand a party was held in Valencia. On hearing the name to be given to the child the Moriscos were saddened:

55. Aznar Cardona, Expvlsion ivstificada, II, 93r-94r. Mountains and hills are frequently depicted in scripture as a place of refuge for those in flight. Aznar Cardona denies such a haven to the unfortunate Moriscos. This scorn for and intense dislike of them is typical of his writing.

56. Baladro del sabio Merlín: Primera parte de La demanda del Santo Grial: Libros de caballerías, ed. A. Bonilla de San Martín, NBAE, VI (Madrid: Bailly Baillière e hijos, 1907), pp. 160-162.

57. CoHn, The Millenium, p. 113.

58. “ Rodrigo Ponce de León”, pp. 248, 250.

59. M M Mou, Colón y su mentalidad mesiánica, p. 33.

60. Milou, Colón y su mentalidad mesiánica, p. 362. Following the death of Frederick II of Hohenstaufen various impostors claimed to be the emperor in resurrected form. Later popular folklore and myth superseded political posturing and many believed in a millenarian figure who, once resurrected, would be a great social and church reformer and a messiah of the poor: CoHN, The Millenium, pp. 113-117. In the late fifteenth century the prophecies concerning the Second Charlemagne were applied to the future Charles V: REVES, The Influence of Prophecy, p. 359. 
[...] dixo un Alfaqui de gran nombre, y buena opinion entre ellos. Felipo y Fernando su hijo nos han de perseguir, el padre nos expelera y el hijo destruy ra to da la gente Mahometana de la otra parte del mar. Y otros Moriscos referia, que cierto Principe de España, que tendria nombre de Fierro, esto es Ferrando o Ferdinando, seria martillo y destruycion de los Sarracenos. ${ }^{61}$

\section{THE NEW DAVID}

In Joachimist millenarian prophecy the image of New David is applied both to a reforming universal emperor and to a saintly pope, or "Pastor Angelicus". ${ }^{62}$ Both the New David and the Encubierto feature in the messianic dreams of the visionary Lucrecia de León (1587-1588) who predicted the establisment a millenarian kingdom which would be founded in Toledo. Then, following the overthrow of the House of Hapsburg, a new kingdom for a select few would be set up and ruled over by a certain Miguel de Piedrola who was given the titles of both "segundo David" and "otro David" ${ }^{63}$ There is also an ambiguous reference to an "encubierto", which may be a reference to Piedrola. ${ }^{64}$ The religious order set up by Piedrola's followers called La Congregación de la Nueva Restauración had as one of its aims the liberation of Jerusalem and the recapture of the Holy Sepulchre. ${ }^{65}$

The title of New David is used by Guadalajara y Javier who applies it to a reforming pope. Spiritual renewal in the Church will follow the overthrow of Islam as the King of Spain will join the pontiff in the campaign to recover Jerusalem. This union of pope and king recalled the idealogy of Joachim of Fiore. The notion that Spain has been singled out by God underlies the phrase "cubierto de la gracia de Dios". (23)

En este medio se leuantara en la Iglesia el epiritu de vn nueuo David, que sera vn Pontifice Romano, escogido por la mano de Dios, el qual reedificara su Iglesia Catholica. [...] Este nueuo Pontifice boluera la Iglesia a su antiguo estado, y reduzira los hereges; y despues de reduzidos, se juntara con el Rey, cubierto de la gracia de Dios: Y los dos tomaran todos los thesoros de las Iglesias, y hecho moneda

61. GuAdalajara Y JAVIER, Memorable expvlsion, fol $160^{\mathrm{r}}$.

62. Joachim of Fiore himself gave the New David a priestly rather th an a secular role: Reeves, The Influence of Prophecy, p. 304. As mentioned before, in Aragon Arnald of Villanova gave the king this title and the eschatological role of the reconstruction of the citadel of Sion: MiLHOU, Colón y su mentalidad mesiánica, p. 235. During the crusades, at different times, both the French king and German emperors were called either a rex justus or New David: MirHou, Colón y su mentalidad mesiánica, p. 234.

63. Milhou, Colón y su mentalidad mesiánica, p. 247.

64. Sueños y procesos de Lucrecia de León (Madrid: Tecnos, 1987), p. 241.

65. Sueños y procesos, p. 137. 
leuantaran gente en la Christiandad, y con exercitu poderoso, marcharan la buelta de Hierusalem. ${ }^{66}$

\section{APOCALYPTIC VISIONS AND CELESTIAL PORTENTS:}

I shall refer briefly to apocalyptic visions and celestial portents. Such phenomena are cited by some of the apologists who claim that they set a divine seal of approval on the policy of expulsion. Aznar Cardona refers to an apocaly ptic vision that is purported to have been seen in Santiago de Galicia in 1609, the year in which the first of the expulsions took place. The Lion, who represents “elrey católico”, and the serp ent or dragon, who represents Islam, the Antichrist, were seen in the sky and between them could be heard Santiago’s war cry “¡Cierra, España, cierra!”:

Lo mismo [the destruction of Islam] significaron los prodigios, y visiones, del año 1609 sucedidos en San Tiago de Galicia, a donde entre la serpiente, o dragon, con sus escuadrones malignos, aparecidos alli en el ayre, y entre el Leon con sus exercitos victoriosos, se percibieron bien aquellas vozes sensibles, $i$ Cierra, España, cierra! , que el Leon (esto es el rey catolico), vence y vencera. ${ }^{67}$

This my thification of Philip III and the association with Santiago Batallador is also found elsewhere among the apologists. ${ }^{68}$

The apologist Damián Fonseca describes many apocalyptic phenomena that occurred in Aragon and Valencia in the early years of the seventeenth century. In 1602, in Aragon, fire descended from Heaven ${ }^{69}$ shortly afterwards, in Valencia, a blood-stained cloud appeared; ${ }^{70}$

66. Guadalajara Y JAVIER, Memorable expvlsion, fol $160^{\mathrm{v}}$.

67. Aznar Cardona, Expvlsion ivstificada, II, 146v. In the margin the author states; “ Hay vna relacion sobre esto”. To date I have failed to locate this. In the Middle ages the Antichrist was often portrayed as a demon or dragon flying in the air and surrounded by lesser demons: CoHN, The Millenium, pp. 17-18.

68. There is a striking example in the epic poem of Gaspar Aguilar. Philip III is depicted as a celestial vision seen by the Moriscos who were resisting the expulsion edict on the Sierra de Laguar. The king appears on a white charger and is trampling underfoot Moorish figures in a way customary in the iconography of Santiago. In fact the description is strikingly similar to a depiction of Santiago by Francisco Ribalta (1565-1628) painted in 1603 at the request of the Patriarch of Valencia, Don Juan de Ribera, for the church in Algemesí, a “lugar de moriscos”: AguILAR, Expvlsion de los moros de España, p. 144.

69. “En el mismo Reyno [Aragón], año 1602, baxò grande fuego del cielo que abrasò la tierra en vn lugar que se llamaua Ambel. Sin duda que enojado el cielo por los grandes sacrilegios y heregias de aquellos blasfemos, ministraua a la tierra el elemento con el qual merecian ser castigados”: D. FonsECA, Ivsta expvlsion, pp. 166-167. In Revelation $(8,4)$, following the playing of the first trumpet, hailstones and fire mixed with blood descended to earth, burning a third of the trees and all of the grass.

70. “En Valencia poco tiempo despues se vio hacia la tramontana por espacio de muchos dias vna nuue muy clara, y en algunas partes manchada de sangre, la qual duraua quatro horas continuas, no con admiracion de los Astrologos de los que la mirauamos, considerando en el fuego, y nuue sangrienta del cielo, que era 
horrendous earthquakes took place in the town of Gandía in Valencia ${ }^{71}$ finally, in September of 1603, in Castellón del Duque, hailstones the size of hens' eggs were seen to fall. ${ }^{72}$ Such apocalyptic horrors were, the author concluded, signs of God's anger at the sacrilege and blasphemy of the Moriscos and his indication that they should be expelled en masse. They were a dramatic continuation of the omens and portents of disaster in a new century that had begun with with the mysterious tolling of the bell in the church in Velilla in Aragon.

\section{RESUMEN}

Los apologistas católicos, en sus obras escritas en la década después de la expulsión de los moriscos, intentaron mitificar al rey Felipe III. Le imputaron el papel del Emperador de los Últimos Días, personaje mítico derivado de las profecías sibilinas medievales (la Tiburtina y la de San Metodio) y de la exégesis bíblica milenaria de Joachim de Fiore. También le atribuy eron el rol del Rey León de España, que relacionaron con el León de Judá; ambas figuras míticas habían de reconquistar Jerusalén y acabar con “la secta de Mahoma”. Según los apologistas el papel del rey como extirpador del Islam fue confirmado p or la gran conjunción de 1603, que los apologistas relacionaron con el horóscopo de natividad del mismo rey.

\section{ABSTRACT}

The Catholic Apologists, in those works written in the decade after the expulsion of the Moriscos, attempted to mythicize king Philip III. They ascribed to him the rôle of the Emperor of the Last Days, a mythical personage derived from Medieval, Sibylline prophecies

la voluntad de Dios, que fuessen echados de España los Moriscos, y si fuesse necessario, a fuego y sangre”: FONSECA, Ivsta expvlsion, p. 167.

71. “En la villa de Gandia y lugares circunuezinos, donde estaua la mayor y peor morisma del Reyno, huuo por este tiempo muchos, y horribles terremotos, y se abria la tierra por muchas partes, de manera que parecia se hazia bocas para tragarse viuos estes Datanes y Abirones”: FonSECA, Ivsta expvlsion, p. 167. Following the opening of the sixth seal in Revelation $(6,12)$ there was an earthquake and after the opening of the seventh seal $(8,5)$, there was thunder and lightning and earth tremors.

72. “A los 13 de Setiembre del año 1603, en Castellón del Duque, lugar de Moriscos, de la villa de Albaida en el Reyno de Valencia, estando por la mañana juntos casi todos los del lugar, y altercando sobre vn caso, que auia acontecido, començò el vno a escharse maldiciones, y señaladamente dixo. Mal remolino me lleue, si esto no es assi. Y luego à la tarde, estand o el cielo sereno y la mayor parte dellos en la plaça, se fue formando vna nuue negra, y creciendo poco a poco, se estendio como vna manga muy escura, la qual començò a granizar piedras gruessas y algunas tan grandes como hueuos”. There later followed a whirlwind that uprooted 700 trees: FonsECA, Ivsta expvlsion, p. 167. These hailstones recalls those of Revelation (16, 21). 
(the Tiburtina and that of St. Methodius) and from the millenarian biblical exegesis of Joachim of Fiore. They also attributed to him the rôle of the Lion King of Spain, which they related to the Lion of Judah; both mythical figures were to reconquer Jerusalem and bring to an end "the sect of Muhammad”. According to the Apologists the king's rôle as extirpator of Islam was confirmed by the great conjunction of 1603, which the Apologists related to the nativity horoscope of the king himself. 